\title{
THE SILC ROAD LOCAL CULTURE PROJECT: OPPORTUNITIES FOR DESTINATION VARNA IN THE BLACK SEA COAST REGION
}

\author{
Stoyan Marinov, Krasimira Yancheva, Todor Dyankov \\ University of Economics-Varna
}

Abstract: The report is dedicated to the project Silk Road Local Culture - SILC-under the Joint Operational Programme Black Sea Basin 2014-2020. The programme is co-financed by the European Union through the European Neighbourhood Instrument and by the participating countries: Armenia, Bulgaria, Georgia, Greece, Romania. The report outlines the opportunities resulting from the SILC Road Local Culture project for Varna in the context of good international practices for the use of the Silk Road cultural and historical heritage for tourism purposes.

Keywords: Silk Road, cultural heritage, tourism masterplan, tourism destination, Varna

\section{Introduction}

The countries on the Silk Road endowed with cultural and historical heritage have a great potential for joint tourism development by creating integrated tourist products. International organisations such as UNESCO, the World Tourism Organisation (WTO) and the European Union (EU) are working actively towards establishing networks of stakeholders for the reassessment of the topic of the Silk Road in the field of tourism.

The project SILC Road Local Culture is implemented under the Joint Operational Programme Black Sea Basin 2014 - 2020, with a period of implementation 2018-2021. Partners in the project are the Aristotle Unversity of Thessaloniki in Greece, the University of Economics in Varna, Bulgaria, the RussianArmenian Unversity in Armenia, the National Association for Rural, Ecological and Cultural Tourism, Tulcea branch in Romania, and the International Centre for Social Research and Policy Analysis in Georgia. The general purpose of the project is to identify, evaluate, map and promote the cultural heritage on the Silk Road, which will be used for the tourism development of the regions located on the ancient trade route.

The aim of the report is to outline the opportunities resulting from the project SILC Road Local Culture for destination Varna in the context of already implemented good international practices for the use of cultural and historical heritage along the Silk Road for the purposes of tourism.

The Silk Road in the Context of Tourism

In the context of tourism, the Silk Road is one of the most interesting and visited tourist routes, distinguished by the numerous sites from the cultural and historical heritage $(\mathrm{CHH})$, many of which are included in the UNESCO World Heritage List. The ancient trade route today is strewn with towns, museums, natural landmarks, different national cultures, traditions, lifestyles, folklore and culinary heritage, which attract tourists of various interests from different countries.

The Silk Road is not an "only road" but a network of roads including a number of different destinations in different countries. The beauty of the Silk Road lies in the fact that it is a transnational route spanning three continents and running through 33 countries. Destinations such as China and other countries in Central Asia have been working on the concept of the Silk Road as an opportunity for tourism development for years. Bulgaria has also joined this initiative.

The chronology of the project work for the tourist routes along the Silk Road shows for how long, how and which stakeholders have been using the potential of the ancient route between China and Europe, Asia and Africa for the development 
of tourism.

In 1988 UNESCO launched a two-year project entitled Integral Study of the Silk Roads: Roads of Dialogue. It includes specific actions for comprehensive study of the history of the ancient routes and establishment of close contacts and partnership between the East and the West. The aim of the project is to conduct field studies on these routes with a view to stimulating further research on both an international and national scale as well as emphasising the complex cultural interactions ensuing from the meetings between the East and the West [10]. The Silk Road has connected civilisations and gathered people and nationalities from all over the world for thousands of years, allowing not only the exchange of goods but also the interaction of ideas and cultures. In this regard, UNESCO's Silk Road online platform has been developed for their dissemination, which is designed to revive and expand these historical networks in a digital space, uniting people and social groups in a continuous dialogue about the Silk Road [8].

In 1993, in a session of the General Assembly of UN in Indonesia, a resolution was adopted on the revival of the Silk Road as an important channel for international cooperation in the field of economy, diplomacy, culture, science, trade and tourism. The concept aims at unification of the ancient routes in one project, spanning 12,000 km. [12].

In 1994, WTO, together with UNESCO, held the first international session The Great Silk Road in Uzbekistan, where 19 countries agreed on the famous Samarkand Declaration for development of the legendary route as a transnational tourist route. In 1996, the new marketing plan was adopted at the international forum of WTO in Xi' an (China), signed by all participating countries. It was attended by representatives of UNESCO, 110 leading managers of tourist companies, scientists and journalists from over 25 countries, tour operators, owners of the largest hotel chains. In Xi'an, WTO has had the opportunity to help the countries along the ancient route for the first time by establishing real business contacts with the tour operators from the main international markets. The activities of WTO on the Silk Road for the period 1993-2011 are as follows: [14]:
1993 - Silk Road Project General Assembly Bali, Republic of Indonesia;

1994 - First International Silk Road Meeting Samarkand, Republic of Uzbekistan;

1995 - Silk Road Events 1994/95: World Travel Market London and at ITB Berlin;

1996 - First Silk Road Travel Forum Xi'an, People's Republic of China;

1997 - Second Silk Road Travel Forum Nara, Japan, Second International Silk Road Meeting Tehran, Islamic Republic of Iran International Silk Road Meeting on Tourism and the Environment Bishkek, Kyrgyz Republic, UNWTO General Assembly Workshop Istanbul, Republic of Turkey;

1998 - Third Silk Road Travel Forum Kyoto, Japan,Silk Road Tour Operators Workshop Almaty, Republic of Kazakhstan, Third International Silk Road Meeting Tbilisi, Georgia; 1999 - WTO/UNESCO Tourism and Culture Seminar Khiva, Republic of Uzbekistan;

2002 - Fourth International Silk Road Meeting Bukhara, Republic of Uzbekistan;

2003 - UNWTO General Assembly Workshop Beijing, People's Republic of China; 2004 The Silk Road Initiative (SRI), The UN Silk Road City Awards;

2006 - First Silk Road Investment Forum Xi'an, People's Republic of China;

2009 - UNWTO General Assembly Silk Road Meeting Astana, Republic of Kazakhstan;

2010 - Shiraz Silk Road Mayors Forum Shiraz, Islamic Republic of Iran, Fifth international Silk Road Meeting Samarkand, Republic of Uzbekistan;

2011 - Silk Road Ministers' Summit at ITB Berlin 2011 Berlin, Federal Republic of Germany, 9-13 March

The initiatives of UNESCO and WTO and projects such as Silk Road Destinations, Silk Road Transatlantic Alliance, as well as Silk Road Travel Association, and Silk Road Network invest in the unique ancient route as an opportunity for amplifying the international cooperation in the field of culture, trade, tourism and science. The project activity of WTO on the Silk Road for the period 2012-2018 has included the following topics [13]:

2012 - The 21st Century Maritime Silk Road 
- Tourism Opportunities and Impacts, UNWTO

/ Pilot Productions joint collaboration: Globe Trekker Round the World 20th Anniversary Special, EHL/UNWTO Silk Road Strategy Challenge 2012, EHL/UNWTO Silk Road Strategy Initiative;

2013 - UNWTO / EHL Altai Krai Hospitality Management Strategy, School of Hospitality Management/Development strategy of hospitality management in Altai Krai, UNWTO / WTM Silk Road Bloggers Trip to Armenia, UNWTO / UNESCO Silk Road Heritage Corridors Tourism Strategy Project, Working meeting of UNESCO on the corridors of the Silk Road heritage;

2014-2016 - VeRoTour Project; 2015 First ever Silk Road training course for heritage guides taking place in Khiva, Uzbekistan; 2016 - ,David Baddiel the Silk Road' to air on Sunday 21 February at 9pm on the Discovery Channel UK, BBC documentary The Silk Road hosted by renowned historian Dr. Sam Willis, Western Silk Road Tourism Initiative, Enhancing Silk Road Interpretation and Quality Guide Training, UNWTO Workshop for Inbound Tour Operators;

2017-2018 - Western Silk Road University Challenge, UNWTO Silk Road Training and Capacity Building Programme.

The WTO has an important role for the revival and promotion of the ancient route through the implementation of the regional Silk Road Destinations project [6]. It unites tour operators from nine different countries on the Silk Road (Armenia, Georgia, Azerbaijan, Turkmenistan, Uzbekistan, Tajikistan, Kyrgyzstan, Kazakhstan and China (Xinjian)) in joint efforts for popularisation of tourist products along the Silk Road in a broader international context. The main goal of the Silk Road Destinations project is: "organisation and promotion on the international markets of various joint multinational tours along the Silk Road on the highest possible quality level at affordable prices". Large-scale tourist projects such as the International Auto Motor Rally and Multinational Tours additionally contributed to the international promotion of the Silk Road.

Silk Road Destinations provides an opportunity for experiencing the culture along the Silk Road through participation in social events, in cultural celebrations and show programmes.
The cultural routes as means of development of sustainable tourism have a central position in the discussions of the ministers of the member countries in The Silk Road programme. The meeting of ministers, which was attended by the Deputy Minister of Economy, Energy and Tourism at the time Ivo Marinov, was part of the biggest tourism trade fair in the world - ITB in Berlin. The meeting was also attended by the SecretaryGeneral of the World Tourism Organisation Taleb Rifai [7]. Europe has one of the widest networks of cultural tourist routes in the world, which gives the continent a serious advantage in the development of sustainable tourism with focus on viability and innovations. That is why in June 2010 WTO devised the first action plan under the Silk Road programme focusing on marketing and promotion of the tourist routes, and building the capacity and management of the destinations.

Bulgaria is working on several transnational tourism projects as a coordinator and partner. Together with Croatia, Serbia and Romania, our country is the coordinator in the project Roman Emperors Route, and is also in cooperation with five Balkan countries in the project Iron Curtain Route. The thematic set of tourist routes that our country actively works on is aimed for the increase of the tourist attractiveness of the region, diversification of the tourist product and the enhancement of competitiveness of the industry.

Bulgaria has been a member of the WTO the Silk Road programme since 2012. Sofia hosted the Second International Seminar The Western Silk Road, held within the Initiative for Development of Tourism on the Western Silk Road in 2017. This was a joint project of WTO and the European Commission and was part of the European initiative Enhancing the Understanding of European Tourism. The aim of this project was the popularisation of the opportunities for implementation of tourist activities in the western stretches of the Silk Road. One of the main ideas of the initiative was to establish tourist routes on the Western Silk Road, and in a longer time span it is expected that this will lead to the intensification of the transnational cooperation between the member countries in the WTO's Silk Road programme [1].

Bulgaria is collaborating with Greece in the 
implementation of the Western Silk Road initiative for the attraction of visitors to Europe from longhaul tourism markets. Bulgaria and Greece are members of the WTO's Silk Road programme. In 2017, they hosted two working seminars on the new Western Silk Road initiative and participated in the creation of a Roadmap under the project through the provision of national analyses. The Bulgarian suggestion envisaged the creation of regional products related to silk, for example, through consolidation of the tourism potential of Greek and Bulgarian towns with traditions such as Soufli and Ivaylovgrad [3].

Characteristics of the SILC Project -

\section{Goals, Activities, Expected Results}

The SILC Road Local Culture (SILC) project as part of the Joint Operational Programme Black Sea Basin 2014 - 2020 continues the initiative of the World Tourism Organisation (UNWTO) for development of the Western Silk Road through tourism from the area of the Caspian and the Black Sea through the Balkan Peninsula on to the way to the Mediterranean and Western Europe. The need to set up the SILC project is determined on the one hand by the availability of a number of resources with potential for their development into specific assets through joint coordinated initiatives, and on the other hand - their insufficient popularisation in the cultural tourism system. In this respect, the main expectations under the SILC project are connected with the stimulation of new business opportunities in tourism against the background of the increasing tourism market along the Silk Road. The revival of the Silk Road from a contemporary point of view is based on the consideration of a new type of tourist flows of individual visitors seeking interaction with the different local cultures outside the range of mass tourism. This emphasises that the main goal of the SILC project is to set a strategic approach for promoting the tourist products on the Silk Road within the European Union and the countries from the Black Sea basin. To achieve this goal, it is necessary to analyse the unrevealed potential of the local cultural heritage on the Silk Road in the above-stated region, as well as to outline the perspectives for establishing new entrepreneurial networks in tourism, bound in common marketing and management strategies.

As mentioned above, the SILC project is developed by a team of representatives of three higher education institutions and two business organisations operating at the respective tourist destinations - beneficiaries from the Black Sea basin. The completion of the main results regarding the achievement of the project goals is planned for May 2021. In the process of development of the project, the partners are supposed to prepare reports on the joint results as well as to contribute with specific activities for the implementation of the stages of the SILC project.

Within the area of the Balkan Peninsula the SILC project covers the territorial parts of Romania and Bulgaria in the so-called Danube microregion. Along this geographical axis, Bulgaria with its Northeastern and Southeastern region seems to be a key element of direct connection along the Silk Road between Romania and Greece on the one hand, as well as in an indirect, overseas exchange with the destinations Armenia and Georgia on the other. The main idea about the tracing of this segment of the Silk Road is the intensification of the social and economic interaction of the Eastern part of the European Union (Romania, Bulgaria, Greece) with partner countries outside the community - Armenia and Georgia. In this aspect, the SILC project is closely related to the following initiatives that precede its emergence [17]: the Western Silk Road Initiative UNWTO / EU that was launched in 1993 under the auspices of WTO and which in 2016 in cooperation with the EU was transformed into a key programme from the Western Silk Road Tourism Development Initiative; the Silk Road Heritage Corridors Tourism Strategy Project UNWTO / UNESCO, 2014, whose focus was on two cultural corridors crossing five countries: China, Kazakhstan, Kyrgyzstan, Tajikistan and Uzbekistan; the Silk Road Bloggers Ch@1lenge 2012 UNWTO / WTM - an event organised in Armenia whose main goal was the intensification of the process of popularisation of the Silk Road in the social media and the World Wide Web; the Black Sea Network for Sustainable Tourism (BS NTS) - stimulating the creation of strategies for joint marketing and economic development in the Black Sea region. 
The SILC project as part of the Joint Operational Programme Black Sea Basin 2014 - 2020 also complies with the priorities from the "common resultative indicators" underlying the European Neighbourhood Instrument for Cross-Border Cooperation 2014 - 2020, such as [17]:

- enhancing the cross-border business opportunities in the field of tourism and culture;

- intensifying the cross-border connections for trade and modernization of the agriculture and the related sectors;

- establishing a level of comparability of the data and information from the conducted cross-border monitoring;

- increasing the level of awareness regarding the challenges from the environment and the good practices in the management of the wastewater discharge in river and marine pollution;

- development of strategies and products for the purpose of joint promotion of tourism;

- organisation of cross-border tourism and cultural events;

- carrying out improvements in small-size cultural and historical sites, landmarks, etc.

In the course of development of the SILC project are envisaged the following stages (phases) [18]:

Conducting a baseline study

Establishing an entrepreneurial network along the local Silk Road network (SILCNET)

Establishing a virtual observatory

Preparation of a manual (handbook) for certification and establishment of the SILCNET label

Communication of the project

The baseline study under the project includes a commitment by each of the partners to prepare a detailed evaluation of the local cultural heritage along the Silk Road in the respective country; to prepare information for mapping the cultural heritage in question and to evaluate the potential for this heritage in terms of tourism and economic growth. In this respect, the local tangible and intangible cultural heritage along the
Silk Road should be distinguished (differentiated) from the general tourism resources within the destination. Hence, its promotion, diversification and development on an inter-regional level appear to be the basic objectives for the beneficiary countries - stakeholders.

The information input for the mapping serves as a foundation in setting up a GIS (geographic information system), whose final result is the creation of an interactive map which should provide visually detailed information about location, size, historical data and other specific features of the local cultural heritage on the Silk Road. This project activity is developed in three directions: identification and registration of the local cultural heritage on the Silk Road; creating profiles of the local cultural heritage, as well as profiles of the respective stakeholders willing to join the SILC label. The products from the mapping and profile creation serve as an input information bank for the so-called virtual observatory.

The evaluation of the potential of the tourism and economic growth of the local cultural heritage on the Silk Road includes the devising of a situation analysis of the researched region with key steps for inventory of the tourism resource potential, the evaluation of the general and tourism infrastructure, the legal and political context, the local stakeholders, as well as the specifics of the tourist demand. The situation analysis also involves identification of the intensity of the tourist interest in visits to the researched region, as well as the degree of coordination of the visions of all stakeholders.

The preparation of a strategic framework for absorbing the potential for tourism growth of the local cultural heritage along the Silk Road is planned as a final result of the baseline study, which is oriented towards:

- popularisation of various local tourist products, which the local stakeholders can unite around and which could be promoted on markets with special interests;

- creation of inter-regional tourist products on the Silk Road and general service standards;

- exchange of experience and 
dissemination of good practices through stimulation of the development of the cultural tourism;

- the intensification of the level of cooperation and managerial competences of the local business on the matters of cultural tourism;

- popularisation of the contribution of the researched regions for the reinforcement of entrepreneurship along the Black Sea Silk Road.

The guidelines from the strategic framework are used to set up a common masterplan for cross-border cooperation, which focuses on the development of the local cultural heritage on the Silk Road having two time horizons -2 and 5 years.

The activity for building an entrepreneurial network along the local Silk Road (SILCNET) aims at penetration into new tourist markets and market segments by making use of the advantages of the masterplan for the researched regions together with the adoption of a common strategic marketing plan. In this respect, on the one hand the SILCNET network is planned to be technically connected to other local and inter-regional networks from the Black Sea basin, and on the other - functionally linked to regional government and non-government organisations. The main expectation from the sharing of a joint strategic marketing plan is the promotion of a diversified tourist brand, adapted to the local cultural heritage through the improvement of the image and effectiveness of the marketing efforts on the Silk Road. The following list of planned results has been identified for the successful realisation of the SILCNET network:

building databases for the participants in the network, including general and extended information about the entrepreneurs - partners, maintained and updated online through a virtual observatory;

preparation of a matrix of the participants in the network - for the purpose of obtaining greater clarity about their influence in the network, their dynamic potential, engagement and inclusion in the respective processes;

development of a common marketing strategy, including a joint strategic marketing plan and a manual of basic guidelines and good practices for the application of the SILC project

The basic motives for establishing the virtual observatory are as follows: the provision of an information platform to the tourism industry, the academia, the management organisations, other businesses and tourists through sharing reliable, comparable, renewable data for the market of the cultural heritage on the Silk Road, for the changes and trends in its development. Provisions are made for the development of a kind of an intelligence centre on the Silk Road, through which all publications from the business and the academia will be collected and shared through a specially organised virtual library regarding the type of tourism, country, themes and other search parameters. The development of a web-based location aware application for identification of the SILC location is planned in its capacity as a key product of the virtual observatory, both in English and in all partner languages. Through this application, the already visualised members of the network of the interactive web-based GIS map at the virtual observatory can also be identified in a cluster manner from the viewpoint of tourism. The main activities planned in the process of establishing the observatory will include: the development of the design of the online platform, such as a multilingual webbased GIS gate, incorporating the capacities of the mobile applications for interaction and sharing experience by everybody; establishment of a web-based repository of data; provision and monitoring of an open geospatial consortium which will feature geographic measurements, pre-defined spatial and attribute queries with the respective symbols, interactive content and other interactive functions; registration of the content of the data coming from the partner destinations; documentation of stories and narratives of ethnographic nature presented by the local communities on the Silk Road.

The idea about creating the SILCNET label is based on a number of devised practices to EU programmes, and is expressed as follows: establishing stable connections between the SILC entrepreneurs; improving the awareness of routes on the local Silk Road; formation of good recognisability and affiliation of each 
SILC entrepreneur to the network of partners and increasing the opportunities for their enhanced competitiveness; establishment and institutionalisation of a permanent cooperation between all stakeholders; optimisation of the management of the capacities on a local level; promotion and support of the small and mediumsized enterprises in the local cultural tourism. As a core activity for the realisation of the SILCNET label the project envisages the conduct of joint cross-border training programmes within the partner destination. The partner in charge of the implementation of this core project activity is the Bulgarian side. In this regard the following actions are to follow:

- preparation of a report for studying the opportunities for realization of the SILCNET label. The document should provide a practical answer to the question in what way the SILCNET network, the virtual observatory and the SILCNET label will continue to exist after the project finalisation;

- creation of a SILCNET logo, which will integrate all certified members from the partner countries in the SILCNET network, as well as promotional materials for the purpose of attracting new entrepreneurs;

- preparation of training materials for the certification sign SILCNET, adapted in accordance with the needs of the local communities from the partner countries;

- preparation of training courses for accepting the SILCNET sign;

- organisation of pilot implementation of the part of the project for acceptance of the SILCNET sign between the partners;

- establishing long-standing partnership agreements between the participating countries outside the field of joint ventures.

The implementation of the communication under the SILC project is planned in several directions:

creation of a design of the project logo;

- identification of the main target groups for communication of the project;

- comprehensive use of the social media for communication of current and already finished project activities;

- devising a communication plan of the project with integrated communication system that effectively covers the project results among all stakeholders from the partner destinations;

- planning communication initiatives and instruments for the project communication - website of the project; electronic newsletter; brochure, poster (banner) of the project; press releases; scientific publications; project manual; participation in conferences; events on a local, national and international level, a webinar for acceptance of the SILCNET label; organisation of a road show of the local cultural heritage along the Silk Road, etc.

The SILC project characteristics also reveal the emerging opportunities for Varna as a tourism destination, namely through complete cultural and economic integration through the Silk Road on all social and managerial levels; contribution of new positive transformations to the mass holiday tourism; improvement of the marketing positioning of destination Varna on the international tourist markets; development of sustainable competitiveness within an environment of dynamic and turbulent conjunctural processes.

\section{Conclusion}

The implementation of the SILC Road Local Culture project will lead to an increase in the internationalisation, connectivity and competitiveness of the stakeholders within destination Varna in the field of sustainable cultural and educational tourism.

The information system of the destination will be enriched with identified, registered, certified and mapped tangible, intangible and spiritual sites from the local cultural heritage on the Silk Road with potential for tourist valorisation.

Varna will obtain a spatial and cultural horizon and priorities for tourist development through the developed strategic framework for absorbing the potential of tourism growth of the local cultural heritage on the Silk Road in the 
Black Sea region, and in a broader perspective, in the cultural and tourist space of the Caspian and the Black Sea region via the Balkan Peninsula on the way to the Mediterranean and Western Europe.

The planned entrepreneur network SILCNET will ensure connectivity of the stakeholders within destination Varna to other local and inter-regional networks from the Black Sea basin, and thus will generate opportunities for new sustainable tourism industry practices.

Varna will be present in the virtual observatory that will offer information services to the tourism industry, the academia, the management organisations, other businesses and tourists through sharing reliable, comparable and updated data about the state and trends of the tourism market of the cultural heritage along the Silk Road.

The tourist entrepreneurs in destination Varna will be able to make use of the marketing effect of the certification label SILCNET. Bearers of the label will participate in the establishment of stable relations amongst the SILC entrepreneurs. They will receive good awareness of the routes along the local Silk Road and will benefit from the formation of good recognisability and affiliation of each SILC entrepreneur to the network of partners. The permanent collaboration which is expected to be established between the stakeholders and institutions through the SILCNET label cooperation will lead to better management of the tourism capacities on a local level, as well as to efficient promotion and support of the small and medium-sized enterprises in the local cultural tourism.

References:

1. Министерство на туризма на Република България // http://www.tourism. government.bg/bg/kategorii/novini/ ministur-angelkova-uchastva-berlinv-devetata-ministerska-sreshta-zaproekta-po

2. Министерство на туризма на Република България. Министър Ангелкова: България и Гърция си партнират по съвместни проекти за привличане на туристи от далечни пазари към Балканите, http://www.tourism. government.bg/bg/kategorii/novini/ ministur-angelkova-bulgariya-i-gurciyasi-partnirat-po-suvmestni-proekti-za

3. СЕГА АД. Туризъм. Пьтят на коприната става туристически маршрут, http:// old.segabg.com/article.php?id=318674. 14.04.2007.

4. Alexieva, Sonya. The silk road as a tourist product: integrating history, culture and economy. New Bulgarian University // http://eprints.nbu.bg/2008/27/Pages\%20 from $\% 20$ TheSilkRoad $2011 . p d f$ (9.09.2019)

5. Bloomberg TV Bulgaria. Пътят на коприната е бил интернетьт на древността, https://www.bloombergtv. bg/v-razvitie/2017-06-27/patyat-nakoprinata-e-bil-internetat-na-drevnostta. 27.06.2017.

6. SilkRoad.Travel. Silk Road Destinations, http://www.silkroad.travel/

7. THEXPERTS „Пътят на коприната“ е в центьра на дискусиите на туристическите министри в Берлин, https:// thexperts.bg/article/,„пьтят-на-коприната“-е-в-центьра-на-дискусиите-на-туристическите-министри-в-берлин. 7.03.2012.

8. UNESCO. The UNESCO Silk Roads Project, https://en.unesco.org/silkroad/ unesco-silk-road-online-platform, 12.08.2019

9. UNESDOC. https://unesdoc.unesco.org/ ark:/48223/pf0000159189

10. UNESDOC. The Silk Roads Project: Integral study of the Silk Roads: Roads of Dialogue, 1988-1997, https://unesdoc. unesco.org/ark:/48223/pf0000159189, 12.08.2019

11. UNWTO // http://silkroad.unwto.org/ content/silk-road-projects

12. UNWTO // http://silkroad. unwto.org/sites/all/files/docpdf/ bannerhistorywebsite.pdf, 13.08.2019

13. UNWTO Silk Road projects, http:// silkroad.unwto.org/content/silk-roadprojects

14. UNWTO. Summary of Silk Road 
Activities 1993-2011 http://silkroad. unwto.org/sites/all/files/docpdf/ summaryofactivities1993-2011.pdf

15. UNWTO. Western Silk Road Tourism Initiative, http://silkroad.unwto.org/ project/western-silk-road-tourisminitiative

16. Ureport.bg. Китай прави фонд от $\$ 16.3$ млрд. за Пьтя на коприната, https://ureport.bg/41176/2014/11/04/ ikonomika/kitay-pravi-fond-ot-16-3mlrd-za-patya-na-koprinata 4.11.2014.

Project documents:

D.T1.1.4 Guidelines for the study
Silk Road Local Culture - SILC: Joint Operational Programme Black Sea Basin 2014 2020, Subsidy Contract No. 99372/31-08-2018

For contacts:

Prof. Stoyan Marinov, PhD

University of Economics - Varna

E-mail:s.marinov@ue-varna

Krasimira Yancheva

University of Economics - Varna

E-mail:

krasimira_yancheva@ue-varna.bg

Todor Dyankov

University of Economics - Varna

E-mail: todordyankov@ue-varna.bg 